\title{
Factors Causing Distress Migration among Bonded Labourers in Nuapada District of Odisha, India
}

\author{
P. Swain, K. Shweta* and B. C. Das \\ Department of Veterinary \& A.H. Extension, C.V. Sc. \& A.H., OUAT, Bhubaneswar, India \\ *Corresponding author
}

\section{A B S T R A C T}

\begin{tabular}{|l|}
\hline Ke y w o r d s \\
$\begin{array}{l}\text { Distress migration, } \\
\text { Bonded labourers, } \\
\text { Nuapada district }\end{array}$ \\
\hline Article Info \\
\hline $\begin{array}{l}\text { Accepted: } \\
\text { 08 January } 2020 \\
\text { Available Online: } \\
\text { 10February } 2020\end{array}$ \\
\hline
\end{tabular}

Every year, a large chunk of workforce from Nuapada district are compelled for distress migration to work in the brick kilns of Andhra Pradesh, Uttar Pradesh and Chhattisgarh. In order to find out the important factors causing distress migration among bonded labourers in Nuapada district of Odisha, the present study was carried out with a sample size of 50 respondents selected randomly from one migratory destination i.e. suburbs of Raipur in Chhattisgarh. The primary data was collected with the help of pre-structured interview schedule. The results of the study revealed that, majority of the respondents strongly agreed that social factors $(43.6 \%)$, economic factors $(61.2 \%)$, livelihood factors $(66.2 \%)$, indebtedness factors (66.8\%) and, support and service factors $(67.8 \%)$ had a bearing on their migration. Among different factors of migration studied, support and service factors got the first rank followed by livelihood factors, indebtedness factors, economic factors and social factors, respectively.

\section{Introduction}

Every year, a large chunk of workforce from Nuapada district migrates out of the state to work in the brick kilns of Andhra Pradesh, Uttar Pradesh and Chhattisgarh. The migration is not with a purpose to make more money and gain affluence; rather it's like an ordeal to repay the loan amount they have taken at the time of urgent need like marriage of children, festival expenses and hospital emergency. The poor labourers don't get any work during the lean agricultural season from harvesting to sowing and their indebtedness compels them to work as bonded labourers in a distressed condition in the brick kilns out of the state. These people are chiefly marginal farmers and landless labourers. As they have meagre patches of land to cultivate, agrarian interventions will be of no help to them. Much to their woe, there is no major or large industry in the district which could take care of their employment plight.

With this background, an attempt was made find out the important factors causing distress migration among bonded labourers in Nuapada district of Odisha.

\section{Materials and Methods}

Fifty migrant bonded labourers were selected randomly from one migratory destination i.e. suburbs of Raipur in Chhattisgarh. The 
migrants were selected on the basis of their experience inmigration (minimum of three years' continuous migration).

The primary data was collected through interview method with the help of prestructured interview schedule. The factors for distress migration were grouped into 5 categories viz. social factors, economic factors, livelihood factors and factors related to support and service, and factors of indebtedness. A total of 50 statements were developed (10 from each category of factors) for collection of data. The responses of the respondents were recorded in a five-point continuum scale and scoring was done as 5, 4, 3, 2 and 1 respectively for Strongly Agree, Agree, Undecided, Disagree and Strongly Disagree which were analysed and the results are presented herewith.

\section{Results and Discussion}

\section{Social factors of migration}

Data in the Table-1reveals that 43.6 per cent of migrant bonded labourers strongly agreed that social factors had a bearing on their migration followed by 16.4 per cent simply agreeing to the fact. However, 2.4 per cent remained neutral. 13.6 per centres pondents disagreed that social factors had a bearing on their migration and 24 percent had strongly disagreed to it. This indicates that social factors had some role inmigration but not all the role.

\section{Economic factors of migration}

From the data in Table-1, it is revealed that 61.2 per cent of migrant bonded labourers strongly agreed that economic factors had a bearing on their migration followed by 18.8 per cent simply agreeing to the fact. However, 3.4 percent remained neutral. 9.4 per cent respondents disagreed that economic factors had a bearing on their migration and 7.2 per cent had strongly disagreed to it. This indicates that people might have migrated without getting any income generating activities in their locality.

The findings of the study are in tandem with the findings of Panigrahi (2009) that 76 per cent of the migrations occurred due to an advance loan taken by the migrants.

\section{Livelihood factors of migration}

Table-1 reveals that 66.2 per cent of migrant bonded labourers strongly agreed that livelihood factors had a bearing on their migration followed by 20.8 percent agreeing to the fact. However, 4.4 per cent remained neutral. 6 per cent respondents disagreed that livelihood factors had a bearing on their migration and 2.6per cent had strongly disagreed to it. This indicates that meagre income from agriculture, the major source of livelihood was unable to check migration.

\section{Indebtedness factors of migration}

From the data in Table-1, it is revealed that 66.8 per cent of migrant bonded labourers strongly agreed that indebtedness factors had a bearing on their migration followed by 13.4 per cent simply agreeing to the fact. However, 0.6 per cent remained neutral. 13.6 per cent respondents disagreed that indebtedness factors had a bearing on their migration and 5.6 per cent had strongly disagreed to it. It indicates that indebtedness that contributed to the migration, might be attributed to lack of any savings at the time of emergencies. Lack of surplus income might have led to debt bondage in case of migrants.

This corroborates the findings of Guerin (2012) who reported that 71per cent of migrations were debt bondage in nature. 


\section{Support and service factors of migration}

Table-1 clearly indicates that, 67.8 per cent of migrant bonded labourers strongly agreed that support and service factors had a bearing on their migration, followed by 22.4 per cent simply agreeing to the fact. However, 5.2 per cent remained neutral and 3.4 per cent respondents disagreed that support and service factors had a bearing on their migration, and 1.2per cent had strongly disagreed to it. This reveals that there existed unscrupulous moneylenders who charge exorbitant rates and govt. was not in any hurry to check them. The exploitation of the respondents by the labour contractor moneylenders might be due to their lack of education and awareness. As support and service factors got overwhelming response against the govt., either it may be attributed to govt. bashing just out of instinct or govt. is callous to the plight of the migrant bonded labourers.
Comparative analysis of factors of distress migration among migrant bonded labourers

In order to know the extent of migration in relation to the five categories of factors, the mean score was calculated for each category of factor and an attempt was made to compare all these mean scores. Accordingly, a rank scale was prepared in a descending order starting from highest to lowest. The responses were also summed up for each type of response in each category and a graph was plotted for the same. The details of these analyses are presented in the table below

Table above revealed that support and service factors got the first rank with a score of 4.52 followed by livelihood factors with a score of 4.42. Indebtedness factors bagged the third position with 4.22 , economic factors fourth with 4.17 and social factors came last in the list with a mean score of 3.42 .

Table.1 Distribution of respondents as per factors of distress migration $(\mathrm{N}=50)$

\begin{tabular}{|c|l|c|c|c|c|c|}
\hline Sl. No. & Factors & \multicolumn{5}{|c|}{ Response (\%) } \\
\cline { 3 - 7 } & & SA & A & UD & DA & SD \\
\hline $\mathbf{1}$ & Social Factors & 43.6 & 16.4 & 2.4 & 13.6 & 24.0 \\
\hline $\mathbf{2}$ & Economic Factors & 61.2 & 18.8 & 3.4 & 9.4 & 7.2 \\
\hline $\mathbf{3}$ & Livelihood Factors & 66.2 & 20.8 & 4.4 & 6.0 & 2.6 \\
\hline $\mathbf{4}$ & Indebtedness Factors & 66.8 & 13.4 & 0.6 & 13.6 & 5.6 \\
\hline $\mathbf{5}$ & Support and Service Factors & 67.8 & 22.4 & 5.2 & 3.4 & 1.2 \\
\hline
\end{tabular}

(SA-Strongly Agree, A-Agree, UD-Undecided, DA-Disagree, SD-Strongly Disagree)

Table.2 Ranking of factors of migration as responded by migrant bonded labourers

\begin{tabular}{|c|l|c|c|}
\hline Sl. No. & \multicolumn{1}{|c|}{ Factors } & Mean Score & Rank \\
\hline $\mathbf{1}$ & Social Factors & 3.42 & V \\
\hline $\mathbf{2}$ & Economic Factors & 4.17 & IV \\
\hline $\mathbf{3}$ & Livelihood Factors & 4.42 & II \\
\hline $\mathbf{4}$ & Indebtedness Factors & 4.22 & III \\
\hline $\mathbf{5}$ & Support and Service Factors & 4.52 & I \\
\hline
\end{tabular}


Support and service factor stopping the list may be attributed to the negative attitude of the migrants who vented their anger by govt. bashing. Livelihood factors coming next to it might be due to the fact that migrants were in a 'survival strategy' mode. They first saw the food security for their families and then went for any other task.

In conclusion the results of the study revealed that, majority of the respondents strongly agreed that social factors (43.6\%), economic factors $(61.2 \%)$, livelihood factors $(66.2 \%)$, indebtedness factors $(66.8 \%)$ and, support and service factors $(67.8 \%)$ had a bearing on their migration. Among different factors of migration studied, support and service factors got the first rank followed by livelihood factors, indebtedness factors, economic factors and social factors, respectively.

\section{References}

Guerin, I. 2012. Ambiguities and paradoxes of the decent work deficit:bonded migrants in Tamil Nadu, Paper submitted to French institute of Pondicherry, 2012: 118-126.

Panigrahi, S.K. 2014. Environmental refugees - the result of another form of forced rural migration.Kurukshetra, 62: 1113.

\section{How to cite this article:}

Swain, P., K. Shweta and Das, B. C. 2020. Factors Causing Distress Migration Among Bonded Labourers in Nuapada District of Odisha, India. Int.J.Curr.Microbiol.App.Sci. 9(02): 11931196. doi: https://doi.org/10.20546/ijcmas.2020.902.140 